\title{
Environmental Communication Based on Local Wisdom in Anticipation of Citarum Flood
}

\author{
${ }^{1}$ IRIANA BAKTI, ${ }^{2}$ HANNY HAFIAR, ${ }^{3} \mathrm{HERU}$ RIANTO BUDIANA \\ ${ }^{1,2,3}$ Fakultas Ilmu Komunikasi, Universitas Padjadjaran, Jl. Raya Bandung Sumedang KM 21 Sumedang, \\ email: 1-irianabaktipr@gmail.com² hannyhafiar@gmail.com, 3 heru.prodihumas@gmailcom
}

\begin{abstract}
Management of watersheds becomes part of a government program. This was conducted to anticipate the floods that hit the settlement. But the program is hard to do without the active role of the community, therefore the communication activities were undertaken based on local wisdom. The purpose of this paper is to find out about the environmental communication based on local wisdom in the Citarum Watershed. The method used is in the form of interviews and participant observation. As for the results obtained are: local wisdom is utilized by the environment actuator in the Citarum watershed management in the form of the proverb, rituals, and the environment preservation. Local wisdom by the environment actuator is meant as a way in, and domain in conducting environmental communication. In addition, local wisdom considered by the environment actuator as the ethic to be met in interacts with the target communities. Implementation of environmental communication activities with local wisdom based on the Citarum is done through a personal approach to some of the social and religious figures by using the communication channels of the group in the forum -the farmers group, majelis ta'lim, and community empowerment, which proceeds in a dialogical way to reach mutual agreement based on mutual trust among the participants of the environmental communication
\end{abstract}

Keywords: environment communication, local wisdom, flood

\section{Introduction}

Citarum is a river that serves as a power plant for the Java and Bali island, as a water provider for rice fields in the north coastal areas, and supplier of clean water to the capital city.According to Riswanda (2010), Citarum watershed has three functions, namely: 1. Ecological Functions, as enhancement of ecosystems and natural resource sustainability support, 2. Social functions, as supporting basic necessities of human life, and 3. Economy function, as a media production or media production assistants. These three functions must be implemented in a balanced and aligned by all stakeholders of Citarum watershed.

In addition, still according to Riswanda (2010), Citarum watershed is an area prone to disasters (particularly floods) caused by: (1) geographically, Citarum watershed structure located on the ranks of active volcanoes (Ring of Fire); (2) The policy factor that arranges the function over of the land, the exploitation of natural resources, and pollution; (3) the condition of forests that already cannot hold water in the rainy season; (4) The condition of water resources in exploitation (underground water and surface water) by industry activities.

As for the understanding of the flood, there are opinions according to Putri (2010) which states that: 
all countries in the world including Indonesia." (Putri, Hakim, \& Yamin, 2016).

The condition of flooding that occurred in the area of Citarum River has become a concern, caused by rapid population, industrialization, as well as over function of the land that causes the Citarum River in both hydrological or biophysical degraded badly. The residents in the Citarum watershed are more than 15 million people where most people depend on their life on the river so that often cause complex problems. The residents in the Citarum watershed is often become victims of flooding in the rainy season and drought in the dry season, as well as being the victims of the pollution of waste, both household waste and industrial waste, especially from the textile industry. Actually, the existence of the disaster disinformation in the disaster-prone areas and local cultural differences in the community of the disasterprone areas are still become the separate issues (Arifianto \& Virhani, 2009).

Citarum watershed restoration from pollution requires a serious effort as well as a lengthy process because the pollution has spread ranging from upstream to downstream. Therefore, it is necessary to conduct communications environment (environmental communication), both in the form of counseling, and advocacy to the stakeholders about the problems of the Citarum watershed, whether from the Government, industry, and society.

Environmental communication activities may be in the form of collaboration that is based on understanding and mutual agreement between the organization of environmental actuators, environmental actuators with the community, and environmental actuators with relevant agencies (village government), based on the freedom to enter the network, attention to local norms, and mutual beliefs. This is in line with the thinking that: Community empowerment is one of the keys to success in running a development of a region. The empowerment program is carried out with models, shapes and different strategies (Nugroho, Hubeis, Saleh, \& Priatna, 2016).

Therefore, in restoring the Citarum watershed should pay attention to local wisdom that the relic is still valid, because in reality, the community residing in the Citarum watershed still runs the local wisdom, neither based on culture as well as those based on religion (Islam). Cultural wisdom approach (Sunda) conducted by the actuator environment by carrying the terms/concepts that became the reference from Sundanese culture in earlier times about the environment. Religious approach taken is to invigorate the boarding school environment, led by the leader of the boarding school and bring up verses of the Qur'an that are associated with the environment.

Both approaches (local traditions and religion) is the fundamental social capital in the area of Citarum watershed system value in running a life together. Based on the results of research conducted by Iing Moch. Ichsan (2009), note that: the existence of traditional values that govern the relationships between man and man, and the relationship between man and the natural surroundings. These values are part of environmental ethical principles needed to be exhumed as a basis for seeking solutions to the problems of environmental degradation which has now become a global issue, the problem of a world without limits. Based on the reality of the Citarum river and its flow through the critical areas where still carry out local wisdom, then the author is interested in conducting research on environmental communication based on local wisdom in the upstream Citarum watershed.

Environmental communication is a process of communication that is strategically planned to support policy formulation and the implementation of projects towards sustainable environmental (sustainable). In practice, communication environment does the study of how individuals, institutions, communities, cultures, distribute, receive, understand and make use of messages about the environment and human interaction with the environment.

Many of the environment actuators is aware that in the implementation of environmental projects and action plans are often limited, due to the success of innovation and solutions offered do not fully become part of the needs of the community. Therefore, the application of character development through environmental communication should be conducted on a regular basis by considering ways of thinking and society behaving (cultural) in order for the environmental program to be effective, sustainable and significant. According to Joon and Rivasintha (2011), Character Education is a system of cultivation of character values to the citizens that includes components of knowledge, awareness or willingness, and actions to 
implement those values, both against God Almighty (the Almighty), themselves, others, the environment, or nationality to become perfect human beings (Insan Kamil) (Zulnuraini, 2012).

According to West and Turner (2007) "We are all incorporated in the cultural community." Whereas according to OECD (1999), in Bakti (2013), the reasons why the success of limited environmental program include fundamental issues arising from how society thinks or behaves:

(1) the assumption from the environment actuator that scientific facts and ecological are convincing and interrelated. (2) high hopes that the knowledge strength of words and image/ impression will resolve to occur problems. (3) the conflict of interest that was contested by the stakeholders are not negotiated with the shareholders. Practical limitations that arise from the absence of a communication strategy to cause failure. For example (a) the systematic and thorough communication that takes into account the public perception and also save the cost is rarely taken into consideration (b). Communication activities are often done on an ad hoc with the sporadic base, mainly using top-down mass media with ignoring the public's participation in the media community. (c) Many decision makers do not know how to incorporate communication strategy in the life cycle of their environmental projects so they are not willing to invest in this field.

Human beings in the course of his life can not be separated with the surrounding nature (environment). Human life in utilizing its environment do so with positive or negative behavior but as people of the civilized human beings more often do things that are positive compared to the negative (except in the circumstance). Positive human behavior in relation to the nature is the environmental wisdom or communities local wisdom that already exists in the life of society since ancient times until nowadays. According to Witular (2007), in Permana (2010:1).

\footnotetext{
"The environment wisdom is a positive human behavior in dealing with nature and the surrounding environment that can be sourced from religious values, customs, tip of the ancestors or local culture, which wakes up naturally in a given community to adapt to the surrounding environment, this behavior evolved into a culture in an area and will develop from generation to generation, in general, local culture or culture area is meant as the culture that develops in an area, which its elements are the culture of the tribes who lived in the area."
}

Local wisdom reflects the identity/ local personality that caused its members able to actualize the potential themselves to survival. According to the Department of social (2006), they have an understanding, program, activities related to implementation, maintain, improve and develop elements requirements and the way its fulfillment, with attention to human resources and natural resources around them (Permana, 2010:2). Therefore, according to Hadi (2006) in Permana (2010:3), "thanks to local wisdom, they can make a life, even can develop in a sustainable way (sustainable development)".

Another term of wisdom is the local genius who first introduced by Quaritch Wales. Anthropologists discussed at length about the notion of local genius (Ayatrohaedi, 1986). Haryati Soebadio said among other things that the local genius is also cultural identity, identity/culture personality which causes the nation able to absorb and cultivate foreign culture to fit the character and capabilities of its own (Ayatrohaedi, 1986:18-19). While Moendardjito (Ayatrohaedi, 1986:40-41) says that the cultural elements of potential areas as local genius because it has proven the ability to survive until now. Characteristics are: (1) being able to withstand the external culture; (2) It has the ability to accommodate external cultural elements; (3) Has the ability to integrate external cultural elements into the indigenous culture; (4) Has the ability to control; (5) Able to give direction on cultural development.

\section{Research Method}

The methods used in this research is descriptive qualitative. The steps of data collection as follows: (1) an in depth Interview. The interview was conducted in depth to get information on the meaning of the proverb and the verses of the Holy Qur'an used in environmental communication activities in the upstream Citarum watershed; (2) In a systematic and participatory observation, Observation in the form of observation of environmental communication activity based local wisdom by noting a symptom of the help of instruments and record it in order to obtain the required data from the informants in the upstream Citarum watershed; (3) Study documentation/library, researchers use a variety of reference related to the reality of the researched documents required, consisting of the words and the images have been recorded without the interference of the researchers, which are available in the form of writing, record, voice, image, and so on.

Informants were selected in this study was the environment that do pop 
communication environment in the upstream Citarum watershed. Triangulation used is source triangulation. As for the data analysis techniques, referring to Nasution (1996:129), namely (1) the reduction of data; (2) data display; (3) take the conclusions and verification.

\section{Approach Local Wisdom Values on Society in The Citarum Watershed}

The environment actuator tries to pay attention to values that are related to the regular local wisdom and conducted by the community. They realize that they should be part of the community itself. Therefore, they utilize local wisdom as a way in to do the communication environment in an environment of the upstream Citarum watershed. The actuator of the environment realizes that local wisdom as the fundamental and profound statement that incarnated in an action full of wisdom still applies in the area, and should be utilized and conserved, both relating to the ritual, saying, and the preservation of the environment.

Based on information from informants, the obtained research results about the prevailing local wisdom in the upstream Citarum watershed environmental according to an interview with Deni Riswandani as follows:

"Approach the wisdom of Sundanese culture made by carrying the terms/concepts that became the reference tempo Sundanese culture used to be about the environment, namely Leuweung kaian, Lamping awian, Legok caian, Tegalan sawahan, hambalan kebonan, while the religious approach is carried out by carrying the concept of man as khalifatul ardh".

Deni Riswandani trying to learn the habits of local people, before entering his neighborhood, then do approach the discernment of the cultural, religious, and the approach used when Deni deliver the message inbound and environment in order to be accepted by the community, Sunda proverbial and religious context is a legacy from the ancestors he had to pass. Furthermore, still according to Deni:

"there are sinom asmarandana eling-eling
mangka eling rumingkang on earth nature
which aims to arouse the awareness of the
Sundanese people to manage the environment.
Get into the circle of Islam, it turns out that
in Islam there is a message that we carry a
mandate from God as khalifatul ard, that we
were created by God, has a task to manage,
create prosperity, including keeping the Earth." In addition to both the proverbial Sunda carried by Deni when entering the community to manage the environment, there is one more local wisdom related to the preservation and maintenance of the forest that is in the form of making the sacred forests that exist in the region of Cijambe (kecamatan Ibun). There are tombs of wali songo lineages which is visited by many people, so it is likely to be developed into tourist places of pilgrimage who has a beautiful environment.

The approach from Aam Aminuddin in implementing the communications management in the environment of the upstream Citarum watershed more to religious things. The same thing is done by Ustad Asep Setiawan who performs management of the upstream Citarum watershed using religious approach. He cited verses from the Quran to reaffirm his explanation about environmental issues. Some of the usual verse he quotes when conducting environmental management activities from the upstream Citarum watershed are Q.S. Al-Qhashas: 77; Q.S Ar-Rum: 41; Q.S Ar-Ra'd: 11.

The other environment actuator, Rival Gilani, approach the ustad who guide his majelis ta'lim. Similarly with other environment actuator, is Fitriani, she performed the upstream Citarum watershed environmental management through religious approach. The entrance paths through recitation makes it easy for Fitriani to perform her activities and they would receive the program. As for Devi Jamatin, as the environment actuator, in managing the upstream Citarum watershed more often approach local wisdom, as he has revealed:

"I always use black clothes, the elderly used to say to try planting, leuweung kaian, Lamping awian, Legok caian, Tegalan sawahan, hambalan kebonan, that's actually my real goal."

Sahidah, as another environment actuator also doing approach through local wisdom in the management of the upstream Citarum watershed. She stated: "we imitate our parents how to plant, mountain functions do not change thus causing less water."

The above Sunda adage always mention by Sahidah when she performs her activities, Sahidah also uses religious approach by selecting majelis ta'lim as a place to pass on the environment information. It's been common for Sahidah to exploit religious approaches because she was a member of the fatayat NU which one of the fields is discussing environmental issues. 
Meanwhile, Eson Tarhasan in conducting environmental management approach using the upstream Citarum watershed of local wisdom through the chatter delivered in environmental conservation activities especially on the protection of water, because the territory plans include water shortage due to land over the function of vegetable plantation into a settlement by building the villas. Similar with the Eson, declared by the other environment actuator, namely Ida Suhara, in doing the Citarum watershed management by using the approach of local wisdom. He declared: "If there are any activities related to culture or concerning art and culture or local traditions, I like to make a link to it, for example, there is the karinding festival then I link the activity with the green activity, prior to the festival, participants planting trees in advance".

\section{The Definition of Local Wisdom Val- ues in Environmental Communication Activities on The Citarum Water-shed Communities}

Other local wisdom is done in his work region is Ngaruwat Lembur which are routinely carried out every year, which in its ritual, Ida uses black clothing and a headband as a form of adaptation and respect for ancestors who also dressed like that. Ida Suhara routinely carry out Ngaruwat Lembur because he is a follower of the trust with his organization named is Budi Daya.

The ceremony of Ngaruwat Lembur is related to the preservation of the environment start with the consent of ijab kabul by slash of the black chicken and black sheep, which according to Ida the meaning is "sing hararideng jeung leungitkeun lampah alam kahewanan, supaya lampah jalan teu cara hewan, ari hewan mah kan sok ngarusak pepelakan batur"

Next Ida Suhara says,

"Ngaruwat Lembur teh seperti pesta rakyat lah, nganuhunkeun kanu atos ngabukakeun nu teu acan, nu bade dongkap, termasuk penyakit musiman nyuhunkeun supaya teu datang deui, kitu kanu rizkina, kanu tanina."

Meanwhile Dede Juhari in conducting the management of upstream Citarum watershed utilizing religious approach and local wisdom by inserting the myth to Ciburial Springs, which there are guards. According to Dede: "He said, in the past, there were people who went missing in the Ciburial springs, there is a large snake, there are ghosts ... it was a myth created in such a way to save and to protect the springs." Nevertheless, Dede revamps the explanation about the myth that to save the Ciburial springs needs to catch the water that is with the tree, so that there are more rational and evidence. In addition, he also likes to insert the proverb "leuweung hejo, masyarakat ngejo," but by Dede, this proverb was tailored to his mission to preserve the environment, i.e. "If the forest is green, then the community is prosperous." Based on the results of the above research, local wisdom are utilized in the communication environment in the upstream Citarum watershed are:

Table 1 Local wisdom and its activities

\begin{tabular}{|c|c|c|}
\hline NO & LOCAL WISDOM & ACTIVITY TYPE \\
\hline 1 & $\begin{array}{l}\text { Local wisdom } \\
\text { related to ritual: }\end{array}$ & $\begin{array}{l}\text { - } \text { making the } \\
\text { sacred forest } \\
\text { - Ngaruwat } \\
\text { Lembur }\end{array}$ \\
\hline 2 & $\begin{array}{l}\text { Local wisdom } \\
\text { related to the } \\
\text { proverb: }\end{array}$ & $\begin{array}{l}\text { - Leuweung } \\
\text { kaian, Lamping } \\
\text { awian, Legok } \\
\text { caian, Tegalan } \\
\text { sawahan, } \\
\text { hambalan } \\
\text { kebonan. } \\
\text { - Eling-eling } \\
\text { mangka eling } \\
\text { rumingkang di } \\
\text { bumi alam } \\
\text { Leuweung hejo } \\
\text { masyarakat } \\
\text { ngejo }\end{array}$ \\
\hline 3 & $\begin{array}{l}\text { Local wisdom } \\
\text { related to the } \\
\text { preservation of the } \\
\text { environment: }\end{array}$ & $\begin{array}{l}\text { the creation of } \\
\text { bamboo water } \\
\text { container. } \\
\text { replanting } \\
\text { families } \\
\text { medicinal plant } \\
\text { - Preservation of } \\
\text { bamboo trees } \\
\text { and palm trees }\end{array}$ \\
\hline 4 & $\begin{array}{l}\text { Local wisdom } \\
\text { relating to religion: }\end{array}$ & $\begin{array}{l}\text { - Qasidah } \\
\text { - recitation }\end{array}$ \\
\hline
\end{tabular}

(source: research result)

In treating nature, rural communities generally have their own unwritten local wisdom because they are dependent upon nature so when they manage the natural ecological values then into its origins. The potential of this sort become very important for the actuator to approach the environment community, because according to Marfai (2012:36), "often the knowledge of local communities about the environment made 
an accurate guidelines in developing life in the community environment", although in line with the times, where the currents of globalization and modernization had already seeped into the countryside so that erode the local wisdom.

For that actuator environment through its interaction with the environment (natural and social), tried to carry back the local wisdom as guidelines for disseminating environmental issues in the management of the upstream Citarum watershed. There are verbal local wisdom, such as payroll, myth, aphorism, and qasidah, as well as verses from the Qur'an with regard to the environment, whereas the non-verbal ritual culture, consists of makes sacred forests, and Ngaruwat Lembur, the preservation of nature, consists of creating bamboo water container, plant family medicinal plants, maintaining bamboo and Palm tree.

\section{Implementation of Local Wisdom Values in Environmental Communica- tion Activities on Communities in The Citarum Watershed}

Utilization of local wisdom is a strategic action undertaken by the environment actuator in the management of the upstream Citarum watershed because, in addition to preserving local wisdom itself, it is also associated with human life and the environment. Local wisdom is utilized by the actuator environment that is like the proverbial verbal, Leuweung kaian, Lamping awian, Legok caian, Tegalan sawahan, hambalan kebonan, portrays ideal environmental conditions that should be conserved. Another adage that carried by the environment actuator in each activity is Elingeling mangka eling rumingkang di bumi alam. This proverb is a warning to the man when he was alive and in the social environment activities. Others are saying leuweung hejo ngejo society, show discernment about the assurance of the sustainability of the forest with human life. As for the myth that is still growing in the area is in cutting down the tree will be wretched or missing.

The above proverbs show the interconnectedness of the environment with human life. Or in other words the proverbs can be used to warn the humans in order to sustain his life. The environment actuator using local wisdom to record and interpret the return values of the elderly used actions to be associated with environmental issues. So local wisdom carried the used as a guide to strengthen the environmental messages delivered environment actuator so they and the community spiritual values will be increased and are more savvy about the harmonious relationship between man and the natural surroundings. This is in accordance with the opinion of Keraf in Marfai (2012:35), "local wisdom also concerns the knowledge, understanding, and customs of human beings, nature, and understanding how the relationship among all the inhabitants of this ecological community should be built".

The environment actuator realizes that to enter the community must understand the values that apply where such communities live. Local wisdom itself is a value that already exists since then and in the case of communal ownership. The actuator environment trying to carry this local wisdom as together belonging and attempt to equally practiced with a society that is adapted to the current situation and condition because according to Marfai (2012:35):

"local wisdom is a dynamic value order and responsive to the developments and changes of time dimension so that local wisdom will enable changes in different time and place and community groups. Local wisdom is not a static thing but changed with time depending on the social bond and order system cultures in society".

The environment actuator when making local wisdom as a guide to achieve objectives in the management of the upstream Citarum watershed bypassing the internalization the absorption form of the values embodied in it, so he has a knowledge of the different themes of local wisdom. According to the opinion of Berger and Luckman (1991:150): "internalization in this general sense is the basis, first, for an understanding of one's fellowmen and, second, for the apprehension of the world as a meaningful and social reality". That knowledge is a provision to reach an agreement in bargaining with the community. This is in accordance with the principles of social learning and information sharing, according to Salman (2012: 131132):

"This principle departs from the assumption that the local wisdom born from the knowledge and knowledge is the result of learning and information sharing. Therefore, behaviour change towards environmental management should be born of a long day of knowledge and information that builds on the experience with the stakeholders. Thus, the required facilitation to take the parties experienced a learning process to solve the problem of specific environment in multi-party and in it social learning takes place and shared learning. This 
principle that drove the inception of agreement on norms that will be adhered together."

Knowledge of local wisdom make the actuator environment has the capability to deliver environmental issues, both regarding the concept of the environment itself (in denotative), and environmental issues that are adapted to the conditions of society (connotative). Knowledge of social wisdom becomes provision for the actuator the environment to create the order of the upstream Citarum watershed environmental quality. This is in accordance with the opinion of Lyotard (2009) in Salman (2012: 114),

\footnotetext{
"knowledge becomes the formation quality foundation because it has the capability to make a good speech expressed in the language game in an order."
}

The environment actuator using his local wisdom knowledge (whether it is verbal like the proverbial and myths are constructed into a story about the risks of taking the sacred forests of trees, as well as such non-verbal like ritual to make sacred forests and Ngaruwat Lembur, as well as the preservation of plants), is not limited only on the language level, but more than that, the environment actuator make that knowledge to determine what to do with the community in the management of the upstream Citarum watershed.

The environment actuator in carrying the local wisdom attempts to equate the meanings of the symbols for words in the form of proverbs and myths and symbols gestures like picking up plastic waste, planting trees, creating bamboo water container, dress in black or Moslem, etc. with symbols that had meant by the community in the sustainability framework of the environment quality and sustainable order. This is in accordance with the statement:

\footnotetext{
"In order to maintain the continuity of a social life, then the actors have to live up the symbols with the same meaning. The processes of thinking, creating, and interact being possible because symbols are important in social groups that have the same meaning and evoke the same reaction in people who use that symbols as well as in people who react to the symbols,". (Raho, 2007: 100-101).
}

The definition against the symbols contained in the social wisdom simplify the environment actuator in carrying out management of the upstream Citarum watershed, because as said by Raho (2007:110-111), the symbols in general and language in particular has a number of functions, among others:

\begin{abstract}
"The symbols allowed humans to relate to the social and material world with allow them to give a name, create a category, and remember the objects they find anywhere; Symbols of perfecting the human capacity to make sense of their environment; Symbols of perfecting human ability to think; Symbols increase the human ability to solve problems; The use of symbols allowed humans to do the transcendence in terms of time, place, and even themselves; Symbols not allowed humans enslaved by his environment."
\end{abstract}

The joint process definition about the local wisdom produce an agreement that local wisdom is used as a guideline for the management of the upstream Citarum watershed because of perceived value and useful for solving problems in people's lives. In other words, according to Hadi (2006) in Permana (2010: 3):

"Local wisdom that later became part of their way of life insensible to solve all life's problems they face. By dint of their local wisdom they can establish life, even can develop in a sustainable way"

Thus, local wisdom carried by the actuator environment is to exist from the substance of the speech, and as a practice of life performed together in realizing the upstream Citarum watershed environmental conditions and quality sustainably. According to UURI No. 32, year 2009 about the protection and management of the environment, explained that:

"Local wisdom is a great value in force in people's lives among other things, to protect and manage the environment sustainably. Further, local wisdom that emerges in a system of life in a society is a form of environmental wisdom." (Marfai, 2012: 35).

The actuator of the environment brings the local wisdom is in order to remind each other, making the guidelines, and to enable them to realize a quality and preserved environmental law because according to Sirta (2003) in Aulia and Dharmawan (2010: 347):

(1) local wisdom works for the conservation and preservation of natural resources (2). Local wisdom works to develop human resource (3). Local wisdom serves as the development of culture and Science (4). Local wisdom serves as a tip, trust, dealerships, and abstinence.

\section{But according to Rahyono (2009: 7):}

"local wisdom is human intelligence, owned by certain ethnic groups gained through the experience of the community. That is, local wisdom, owned by the people of Pangandaran was a result of their own experiences and not necessarily experienced by other communities. These values will be very strongly attached to Pangandaran society and the values it's been 
through a long passage of time, throughout the existence of the society" (Komariah \& Subekti, 2016).

Local wisdom that have been mutually agreed by the actuator to the environment and community as a guideline and be binding in environment management of the upstream Citarum watershed. This is in accordance with the opinion of Permana (2007: 6), "every community has a variety of media to bind its members which can be done through religious rituals or ceremonies and other events."

The ritual is a form of local wisdom who harnessed the environment actuator in managing the upstream Citarum watershed in the form of making the sacred forest, and ngaruwatlembur as a cultural approach, while the rituals pertaining to religion, is something that is done with Majelista'lim. The rituals related to the culture, and the religion is a form of local wisdom as a practice of life. While the proverbial and myths are the pre conditions towards the life practice. According to Salman (2012:116):

\begin{abstract}
"The power to rise from a local wisdom, in order to be implemented in practice life, lies in the spirit of the language and the social environment, in which the local wisdom of it being there. That is good manners. One sense and meaning can be expressed in a variety of languages since each language can be expressed the understanding and the meaning of anything; but the style and feel of the pronunciation of the letters of the word and word arrangement stringing sentences, would differ between languages, and therefore the rise of power between different social sphere where it partially exists. Therefore, local wisdom is indeed ideally solved with a thorough on the language game in their local conditions."
\end{abstract}

Local wisdom in the form of the proverbs above use the Sundanese language that surely will understand the context of his manifestation by them (the actuator environment and society) that understand Sundanese language, although in reality, areas such as Majalaya is the urban area because it is an industrial area where many industry workers who come from other ethnic (mainly from Javanese ethnic). But they could adjust to the meaning contained in the proverbial. This is proven by numerous citizens from the ethnic non-sunda that participated in the management of the upstream Citarum watershed. In addition, the actual communication environment should also be held with in collaboration with private companies, because protecting the environment or maintaining environmental sustainability efforts, is part of the five pillars of CSR activities (Rakhmawati \& Sani, 2016).

\section{Conclusions}

Local wisdoms are utilized by the environment actuator in the management of the upstream Citarum watershed in the form of the proverb, rituals, and the preservation of the environment. Local wisdom related to the proverb, as "Leuweung kaian, Lamping awian, Legok caian, Tegalan sawahan, hambalan kebonan", "Eling-eling mangka eling rumingkang di bumi alam", and "Leuweung hejo masyarakat ngejo". Local wisdom related to rituals, such as making the sacred forest and Ngaruwat Lembur. Social wisdom related to preservation of the environment, such as, the making of bamboo water container, replanting families' medicinal plant, and preservation of bamboo trees and palm trees. While the local wisdom related to religion in the form of the arts of qasidah and study that explores the verses of the qur'an that relate to the preservation of the environment.

The local wisdom is meant by the environment actuator as the entry, and domain in the environment communication in the upstream Citarum watershed. In addition, the utilization of local wisdom by the environment actuator is the ethics that should be run to interact with the community which was the target of the communication environment in the area.

Implementation of communication activities of local wisdom-based environment in the upstream Citarum watershed is done through a personal approach to some social and religious figures by using the communication channels of the group like the farmer-forum groups, forum majelis ta'lim, and training/ community empowerment forum, which took place in dialogic to reach common ground and mutual agreement based on mutual trust among the participants of the environmental communication.

\section{References}

Arifianto, S., \& Virhani, M. R. (2009). Disaster Information And Local Culture (case of Tackling flooding in the village of Bukit Duri subdistrict of South Jakarta). Information Dissemination of The Disaster Risk Reduction In Disaster-Prone Areas, (Informasi Bencana Dan Budaya Lokal (Kasus Penanggulangan Banjir di Kelurahan Bukit Duri Jakarta Selatan). 
Diseminasi Informasi Pengurangan Resiko Bancana Di Daerah Rawan Bencana), Puslitbang Aptel SKDI Balitbang SDM Kominfo, 1-30.

Aulia, T, \& Dharmawan, A. (2010). Local wisdom in the management of water resources in the village of Kuta (Kearifan lokal dalam Pengelolaan Sumber Daya Air di Kampung Kuta), Jurnal Transdisiplin Sosiologi, Komunikasi, dan Ekologi Manusia, Bogor: Dept. Sains Komunikasi dan Pengembangan Masyarakat, Fakultas Ekologi Manusia, IPB.

Ayatrohaedi (1986). The Nation's Cultural Personality (Kepribadian Budaya Bangsa), (Local Genius), Jakarta: Pustaka Jaya.

Bakti, I. (2013). The Construction of The Meaning of The Communication Environment In The Management Of The Upstream Citarum Wareshed, Dissertation. (Konstruksi Makna Komunikasi Lingkungan Dalam Pengelolaan DAS Citarum Hulu, Desertasi). Bandung: Fakultas Imu Komunikasi Unpad.

Cox, R. (2009). Environmental Communication and the Public Sphere, 2nd edition, Sage Publications.

Flor, A. (2003). Environmental Communication. Diliman, Quezon City, Philippines: University of the PhilippinesOpenUniversity

Ichsan, I. (2009). Indigenous Environmental Ethics Kasepuhan In Forest Management in The National Park Region Mount Halimun Salak Inspiration Of Taoism, Dissertation (Etika Lingkungan Masyarakat Adat Kasepuhan Dalam Pengelolaan Hutan Di Kawasan Taman Nasional Gunung Halimun Salak Inspirasi Taoisme, Desertasi), Yogyakarta: Program Pascasarjana Fakultas Filsafat Universitas Gadjah Mada.

Komariah, K. \& Subekti, P. (2016) The Role Of Public Relations In The Development Of Ecotourism Destinations As Pangandaran Beach Through Local Wisdom of Pangandaran Society (Peran Humas Dalam Pengembangan Pantai Pangandaran Sebagai Destinasi Ekowisata Melalui Kearifan Lokal Masyarakat Pangandaran). Jurnal Kajian Komunikasi. Vol 4/2. 173184.

Marfai, M. (2012). Introduction To The Environment Ethics And Local Wisdom (Pengantar Etika Lingkungan Dan Kearifan Lokal), Yogyakarta: Gadjah Mada
University Press.

Mulyana, D. (2006). Qualitative Research Methods (Metode Penelitian Kualitatif), Bandung: Remaja Rosdakarya.

Nugroho, D. R., Hubeis, A. V. S., Saleh, A., \& Priatna, W. B. (2016). Model of Communication in Corporate Social Responsibility Program to Empower Communities. Jurnal Mimbar, 32(2), 254-266.

Permana, R.C.E. (2010). Local Wisdom of Baduy Community In Disaster Mitigation (Kearifan Lokal Masyarakat Baduy Dalam Mitigasi Bencana), Jakarta: Wedatama Widya Sastra.

Putri, N. E., Hakim, N., \& Yamin, M. (2016). Ecologicall Footprint and Biocapacity Analysis for Flooding Prevention in South Sumatera. Jurnal Mimbar, 32(1), 58-64.

Raho, B. (2007). The Theory of Modern Sociology (Teori Sosiologi Modern), Jakarta: Prestasi Pustaka.

Rakhmawati, R., \& Sani, A. (2016). The Implementation of The Corporate Communication Activities Of The Corporate Secretary Division PT Bio Farma (Persero) (Implementasi Kegiatan Corporate Communication Oleh Divisi Corporate Secretary Pt. Bio Farma (Persero)). Profesi Humas, 1(1), 40-52.

Riswandani, D. (2010). The Increased Capacity of The Environment Actuator and Documents Drafting of Action Plan Sinergisitas and Citarum Song Launcing. The Workshop Report, Bandung (Peningkatan Kapasitas Penggiat Lingkungan Dan Penyusunan Dokumen Rencana Aksi Yang Sinergisitas Serta Launcing lagu Citarum. Laporan Workshop, Bandung): PKK-DAS Citarum.

Salman, D, 2012, Sociology Of The Village: Silent Revolution and Dance Of The Complexity (Sosiologi Desa: Revolusi Senyap dan Tarian Kompleksitas), Makasar: Ininnawa.

West, R and Turner, L (2007). Introducting Communication Theory, Third Edition, Singapore: McGraw Hill.

Zulnuraini. (2012). Character education: concept, implementation and development at elementary school in Kota Palu (Pendidikan Karakter: Konsep, Implementasi dan Pengembangannya di Sekolah Dasar di Kota Palu). Jurnal DIKDAS, 1(1). 